\title{
Drivers of Land Cover Dynamics for Pugu and Kazimuzumbwi Forest Reserves in Kisarawe, Tanzania
}

\author{
Makarius Victor Mdemu1, Marco Mathias Burra² \\ ${ }^{1}$ Department of Regional Development Planning, Ardhi University, Dar es Salaam, Tanzania \\ ${ }^{2}$ Department of Urban and Regional Planning, Ardhi University, Dar es Salaam, Tanzania \\ Email:mak_mdemu@yahoo.co.uk, bura@aru.ac.tz
}

How to cite this paper: Mdemu, M. V., \& Burra, M. M. (2016) Drivers of Land Cover Dynamics for Pugu and Kazimuzumbwi Forest Reserves in Kisarawe, Tanzania. Open Journal of Forestry, 6, 348-360. http://dx.doi.org/10.4236/ojf.2016.65028

Received: June 28, 2016

Accepted: August 28, 2016

Published: August 31, 2016

Copyright $\odot 2016$ by authors and Scientific Research Publishing Inc. This work is licensed under the Creative Commons Attribution International License (CC BY 4.0).

http://creativecommons.org/licenses/by/4.0/

(c) (i) Open Access

\begin{abstract}
Forests that are close to growing urban centres have been subject to constant deforestation and degradation from various factors. This study assesses the drivers of land cover dynamics in Pugu and Kazimzumbwi forest reserves in the context of urban and peri-urban expansion of Dar es Salaam for the past three decades. The study adopted review of relevant literature and household survey from three settlements surrounding the forest reserves. One hundred and fifty (150) households were collected from Buyuni, Chanika and Masaki in Ilala and Kisarawe and administered with semi-structured questionnaire to collect information on migration, use of forest products by communities and perception on climate change and variability. SPSS computer program was used to analyse the questionnaire data while tables and graphs were adopted for presentation of the results. Rural-urban and internal urban migration in Dar es Salaam was identified as one of the primary drivers of land cover dynamics in peri-urban areas and adjoining environments. The migration was intensified by push drivers which include urban growth, market of land and reliance on forest product among community members as source of their livelihoods. The increased rainfall variability accompanied with high temperature has contributed to frequent droughts which compromises rainfed agriculture. Thus, the successful conservation of the forest will require strengthened enforcement of protection measures supported with introduction of alternative livelihood strategies for majority of poor community members.
\end{abstract}

\section{Keywords}

Climate Change and Variability, Driver, Forest Reserve, Land Cover Dynamics, Peri-Urban 


\section{Introduction}

Forests that are close to growing urban centres have been subject to constant deforestation and degradation from urban and peri-urban land use changes and unsustainable forest resource extraction to support livelihoods of forest dependent populations. According to de Sherbinin (2002), land use change is a proximate driver of land cover change. In peri-urban areas land use change occur in two main transitory stages. First land which is covered by forest is converted into agricultural lands to produce food crops and other agricultural products demanded by the population in the city centre. For example, in the early 80s, peri-urban areas of Dar es Salaam were being farmed to supplement low income employees in the urban centre (Briggs \& Mwamfupe, 1999). As urban areas expand, agricultural lands are converted into residential or industrial settlements. Trends of land use changes from agriculture or forests to urban uses are a global phenomena which pervade across the continents. Since 1970s, the built up areas of the cities in rapidly urbanizing parts of Latin America and Asia was doubling after every 15 to 20 years (Lupala, 2001). When the annual average population increase of urban areas was 56 million between 1975 and 2000, about 267,000 hectares of land were transformed from peri-urban and rural lands to the urban fabric (UN-Habitat, 1999 in Lupala, 2001). Recent global estimates indicate that by 2020 the land used for urban areas will at least double that of 2000 (Fragkias et al., 2012). These changes will occur at the cost of high quality agricultural and biodiversity land (Tockner \& Stanford, 2002).

According to Wang et al. (2005), increase in population coincides with increase in settlement and urban areas. Therefore, urban population growth emerges as primary driver of urban and peri-urban land use change and forest cover change on two fronts. Firstly, growing urban population contribute to increased requirement of land for settlement and other physical and social infrastructures. Settlement and physical infrastructures develops by converting agricultural and vegetative lands. Secondly, a proportion of the population that have settled in areas that once used to be agricultural lands would entirely derive their livelihood from surrounding forest. Firewood, charcoal, construction materials, medicinal plants and edible fruits are some of the goods and services which are extracted from peri-urban forests at local level. Apart from supplying local requirements of peri-urban areas, exploitation of the peri-urban forests is practiced to meet the demand for forest goods and services in the city. Cities have always exploited the local forests, clays, sand, gravels and rocks of their intermediate hinterland to build shelter and infrastructure (Douglas, 2006). However, in the absence of proper management strategies, the teleconections between cities/urban areas and their immediate hinterlands will contribute to degradation and deforestation of peri-urban forests and ultimately altering ecosystem services. By altering ecosystem services, changes in land use and cover affect the ability of biological systems to support human needs, and such changes also determine, in part, the vulnerability of places and people to climatic, economic or socio-political perturbations (IHDP, 2005).

The dynamics in urban land use changes of Dar es Salaam show rapid increase in spatial expansion of built up areas over years. Between 1891 and 2002, the extent of the 
built up area of Dar es Salaam increased from 122 ha to 57,211 ha. Exponential expansion is noticeable starting from 1963 to the last decade where the built-up area increased from 3080 ha in 1963 to 57,211 ha in 2001. This expansion has had considerable impacts on forest in the neighborhood of peri-urban Dar es Salaam including the Pugu and Kazimzumbwi Forest reserve. Within the last three decades, closed forest cover in the reserves has decreased by almost 30\% to $40 \%$ (Mdemu et al., 2012). Although changes in forest cover have been attributed to a number of factor including increase in demand for land for settlement (Malugu, 2007), there is no systematic assessment and documentation which exists on the drivers of land cover dynamics of the forest reserves. This study therefore assesses the drivers of land cover dynamics in Pugu and Kazimuzumbwi Forest Reserves for the last three decades (1980-2010). Apart from known normative drivers of land cover and land use changes, the emerging driver of climate change and variability is explored.

\section{Materials and Methods}

\subsection{Description of the Study Area}

Pugu and Kazimzumbwi Forest Reserves are located approximately 20 - $25 \mathrm{~km}$ southwest of Dar es Salaam at Latitude $7^{\circ} 10^{\prime} 0^{\prime \prime S}$ and Longitude $38^{\circ} 49^{\prime} 60^{\prime \prime E}$ (Figure 1). The forest reserves are located opposite to each other and encircle Kisarawe Township. The forests are among the oldest coastal forest reserves in Tanzania and makeup to the coastal forest of East Africa which have long been known to be of interest and importance for biodiversity conservation. Kazimzumbwi Forest Reserve was gazzeted in 1936 and covers an area of 5377 hectares while Pugu was gazzeted in 1954 and has an area of 2419 hectares. The forest reserves contain four main vegetation types which include dry

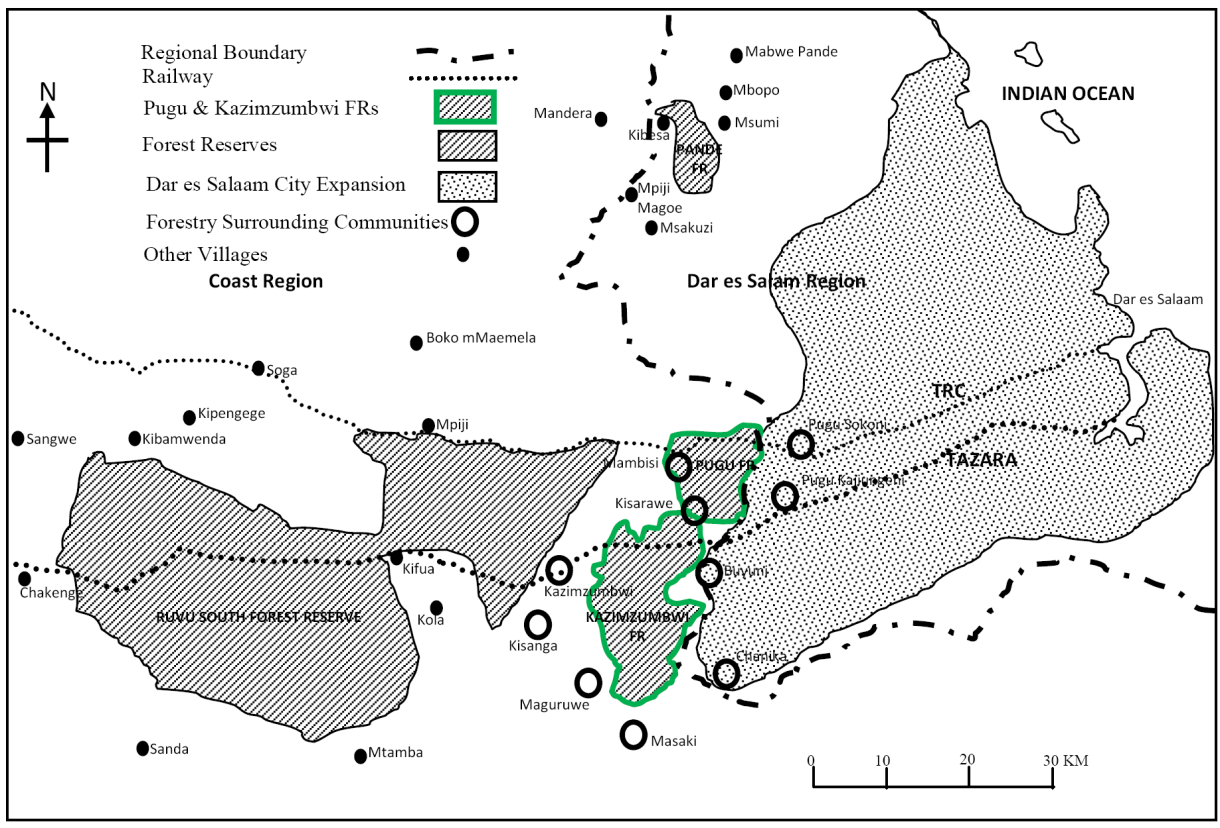

Figure 1. Location of the study area. 
forest found on some of the ridges and hillsides, moist forest with an extra groundwater supply of moisture along the water passages and in the steeper-sided valleys, and dense impenetrable thickets on many of the ridge tops (Ahrends et al., 2010). The study area experiences costal tropical climates with warm temperatures for most period of the years. Temperature ranges between $24^{\circ} \mathrm{C}-31^{\circ} \mathrm{C}$. The area experiences two rainfall regimes, a shorter rain season (Vuli) between October to December and the main rain season (Masika) between March and May.

In the north of Pugu forest and eastern part, the forests are surrounded by peri-urban settlements of Pugu Kajiungeni and Chanika which administratively are located within Dar es Salaam region. The forests are also surrounded by a series of villages in Kasarawe District on the southern part of Kazimzumbwi and on the western side of both forest reserves. While the forest surrounding settlements in Dar es Salaam present peri-urban characters of settlement with rapid growth both in terms of population and land use changes, settlements in Kisarawe are much more rural in characters. Against this contrast of forest surrounding settlement, three settlements (Chanika, Buyuni and Masaki) were selected for assessment of socioeconomic drivers of land cover and land use changes in the forest reserves.

\subsection{Methods}

One hundred and fifty (150) households (50 households each from Buyuni, Chanika and Masaki) were sampled and administered with semi-structured questionnaire to collect information on socio-economic conditions, main livelihood activities and community's perception on climate change, impacts and adaptations. The sample households represented more than $5 \%$ of the total household for Zavara and Chanika Yongwe streets in Buyuni and Chanika respectively and Gumba sub-village in Masaki. Village household registers constituted the sampling framework of the interviewed households. A systematic sampling approach was followed by picking every fifth household from the village household register for semi-structured interview. The interview was administered in August 2012. Five enumerators were identified and trained on how to conduct the interview of the selected households. The interview process was conducted at the houses of the respondents and about one interview process took about forty five minutes. Collected questionnaire data were coded, entered into a computer and analyzed with SPSS program. Focus group discussions were conducted with the environmental committees and leaders of the sample areas to identify the perception of the communities on climate change and variability and how such changes and variability affect the livelihood of farmers and the conservation of the forest reserves.

\section{Results and Discussions}

\subsection{Rural-Urban and Internal Urban Migration}

Rural urban migration is one of the primary drivers of land cover/use dynamics in periurban areas and adjoining environment. According to Muzzini and Lindeboom (2008) Rural-to-urban migration is the "natural" direction of geographical mobility, as economic growth induces a spatial shift in the distribution of economic activities in favor 
of urban centers, freeing up manpower that can be utilized by the urban economies. However, a multitude of factors are described in literature as push factors for rural-urban migration in sub-Saharan Africa. The factors include rural poverty and lack of basic infrastructures and social services such as roads, water supply, access to markets, health and education. Rural poverty in Tanzania is influenced by low productivity in agriculture and youth unemployment which is attributed among others by lack of skills, training and credit facilities. These problems affect youths in rural areas, particularly those who have just completed primary education resorting to urban migration. The perception for majority of unemployed rural population is to improve their living standards through migration to urban areas. Migrants to urban areas also anticipate enjoying better social services and economic opportunities. As result, rural-urban migration significantly contributed to the dramatic population growth of Dar es Salaam over the last four decades (Kombe, 2010). In the last three decades the city sustained high annual population growth rates ranging between 4.5 and 8 percent (Kombe, 2010). The city population doubled between 1978 and 1988 and between 1988 and 2002. It is estimated that on average $16 \%$ of the city population is migrants (Kebede \& Nicholls, 2011). The growth of population for Dar es Salaam City is directly related to population growth in its peri-urban areas. Between 1978 and 1988 the population in the study periurban areas increased thrice in Pugu (Stesheni and Kajiungeni), nine times in Chanika, and two times in Buyuni and Kisarawe. The 1988 population was doubled in 2002 for all of these peri-urban areas. With the exception of Kisarawe, the 2012 projected population has also doubled since 2002. Analysis of the origin of population in Buyuni, Chanika and Masaki revealed that $57 \%$ of the sample population originated outside from Dar es Salaam and Coast Region. The population originating from Dar es Salaam and Coast regions represented only $9 \%$ while those originating within Ilala and Kisarawe districts represented $11 \%$. The population native in the study peri-urban areas of Buyuni and Chanika represented two and one percent respectively. This implies that for every 100 households there are only two households which are native to Chanika and one household which is native to Buyuni (Figure 2). Also the analysis reveals that the size of immigrant population decreases as the distance increase from the peri-urban to the rural areas in Kisarawe. For example, Masaki village which is located about $15 \mathrm{~km}$ from Kisarawe town had $20 \%$ of respondents who are native to the village compared to $2 \%$ and $1 \%$ for Buyuni and Chanika respectively.

The migration pattern in the research areas shows that communities near the forest reserves, in particular the existing peri-urban areas of Pugu (Kajiungeni \& Stesheni), Buyuni and Chanika experienced population increase from the late 1990s due to immigration from Dar es Salaam City (Figure 2). According to FGDs, people migrated to the area in Chanika from 1980 to acquire agricultural land. They started to engage in charcoal production in 1982 and in 1985 they established permanent settlement to the areas. Similarly areas in Buyuni experienced increased migration trends in the 1980-1990 periods. For example, fifteen percent (15\%) of the sample population in Buyuni migrated from Dar es Salaam and settled to the area in 2000 while other migrants targeted 


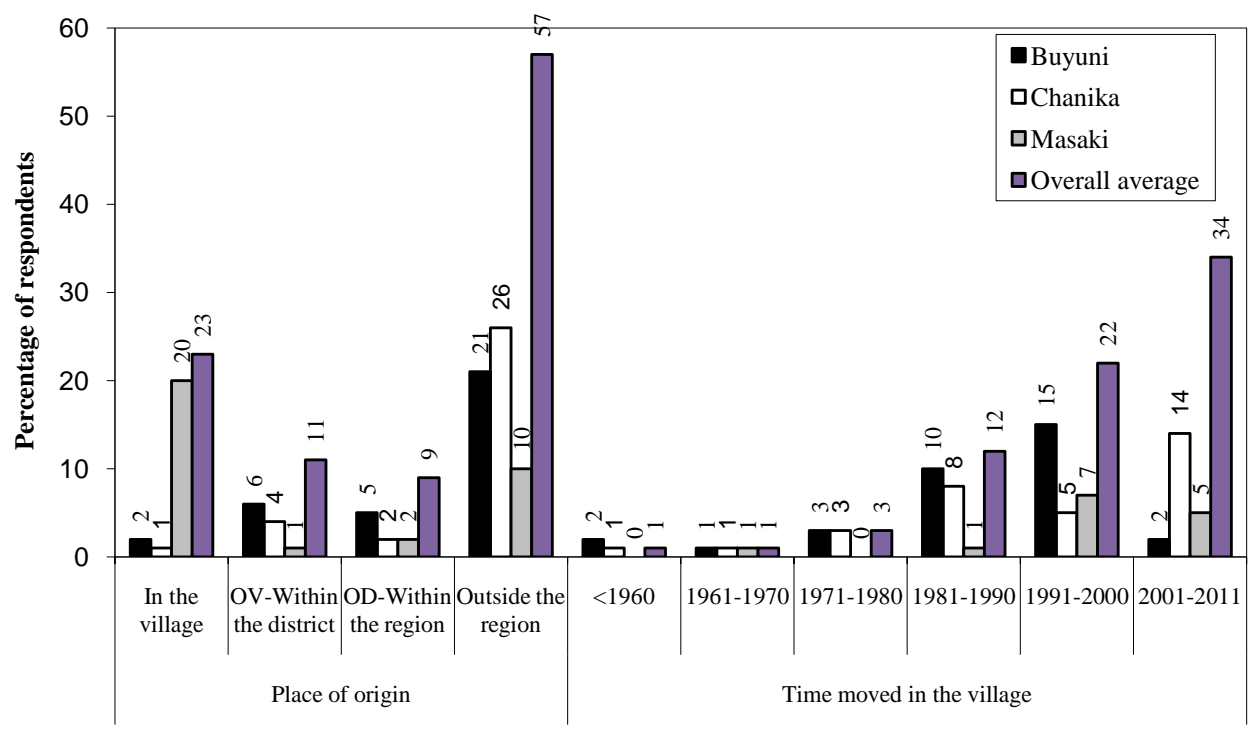

Figure 2. Respondents place of origin and the period they moved to the communities (OV-Outside the Village; OD-Outside the district).

acquisition of agricultural land. The three step migration process illustrates that, not all migrants establish in peri-urban areas immediately, but rather in stages starting with land acquisition. In the process of establishment, acquired land is cleared to make charcoal and or farming plots followed by construction of settlements. However, peri-urban areas are still the most preferable habitats to rural migrants when they arrive in the city for the first time. Characterized with unplanned settlement, residential accommodation in these areas is generally affordable by low income inhabitants due to low population densities compared to the middle zone or in the city centre.

\subsection{Land Market in Peri-Urban Areas for Different Economic Activities}

In the late 1980s, peri-urban areas were being used by low income families living in Dar es Salaam city as areas of survival to cope with economic hardship. The families used peri-urban areas for farming in order to supplement their income or household food basket earned from employment in the city. However, in the early 1990s, peri-urban areas became the subject of attention not only by rural migrants and low income households but also by medium and high income families. This attention contributed to the growth of land markets in the peri-urban areas. Before 1995, more than $70 \%$ of periurban households had acquired land through allocation by the village government or inheritance and only 27\% had purchased the land (Kironde, 2001). However, by 2001, land acquisition in the areas was through purchasing by almost $80 \%$ of households leaving only a minority that obtained through inheritance or village government allocation (Kironde, 2001). According to Briggs and Mwamfupe (1999) between 1990 and 1998, land in the peri-urban areas had appreciated fifty times from Tshs 100,000 to Tshs 5 million. The currently increased proliferation of land markets and speculation in peri- urban areas is partly catalysed by the enactment of the National Land Act (Kombe, 
2010). The Act recognises the value and transaction of bare land. Therefore, the presence of land markets in peri-urban areas clearly indicates that frontiers of land dynamics are not restricted to low income population but to diverse income groups and multiple uses including commercial activities. The prevalent land markets in those areas push land holders in peri-urban to sell their land to new comers. Once the land holders have sold their lands they encroach to the protected forest reserves for housing construction and agriculture activities.

\subsection{Urban Growth}

Rural-Urban migration impacts urbanization through various ways. First, migration has labor-market implications. The skill profile of migrants affects the labor demand in the receiving urban centers. In addition, migratory pressures create additional demand for land, housing, basic infrastructure and social services to urban authorities (Muzzini \& Lindeboom, 2008; Msangi, 2012). These demands have contributed to the dynamics of land use for the last three decades in the peri-urban areas of Dar es Salaam. The dynamics are influenced by the forces of rural-urban migrants and growth of land markets which attracts middle income and high income families from the city to acquire land for various investments including commercial agriculture and housing development. By 2002 the Dar es Salaam City had already expanded spatially to $32 \mathrm{~km}$ northwards along Bagamoyo road, $28 \mathrm{~km}$ westwards along Morogoro road, $20 \mathrm{~km}$ along $\mathrm{Pu}$ gu road (location of this study) and 14 Kilometers southwards along Kilwa Road (Lupala, 2002). This expansion over the past two decades contributed to increased pressure on the protected forest reserves from encroachment of peri-urban settlement. As urban growth intensified in the peri-urban settlements of Dar es Salaam, residents started encroaching forest reserves creating conflicts with the government. There have been about five operations by the Government to remove out residents from Chanika who encroached the southern part of Kazimzumbwi protected forest in 1998, 2002, 2007, 2011 and 2015. Encroachment into the forest reserve for residential houses and farms was attributed by a number of factors including densification of chanika settlement, increased informal land transaction and weak enforcement of the forest protection laws by the forest officers.

Chanika is one of the highly densified peri-urban settlement surrounding the Kazimzumbwi protected forest reserve. Densification in Chanika has been triggered by the rapid population increase including the designing and allocation of planned plots in Chanika as part of the 20,000 plots project in Dar es Salaam. The planning of residential plots in Chanika and Buyuni also triggered informal land transactions where traditional settlers of the areas surrounding the reserves sold land to new comers. The traditional settlers uprooted the beacons of the forest boundary to create land parcels for selling to new comers from Dar es Salaam. Densification and encroachment due to population increase have contributed to the degradation of the forest reserves. According to Malugu (2007), between 1991 and 2000, woodland land cover that was converted into grassland with mixed cultivation accounted for 50 percent. The degraded woodlands were mainly at the southern part of Kazimzumbwi forest reserve near Chanika Village 
where encroachments were very high. The establishment of Nzasa sub-village to the southern part of Kazimzumbwi contributed much to the degradation of the reserve and raised much conflict between the forest manager and the communities (Malugu, 2007). Fast growing peri-urban centeres like Chanika act as population pull centres, both from urban centres and rural areas resulting into increased pressure on land for settlement development and increased demands on forest goods and services by the population. In the absence of effective enforcement for forest protection, non forest based alternative livelihoods and alternative sources of energy to wood fuel, the forest reserves will continue to remain vulnerable to encroachment.

\subsection{Forest Product Extraction}

Intensified extraction of forest products influences the dynamics of land cover change within Pugu and Kazimuzumbwi protected forests. Activities which contribute to such dynamics include charcoal burning, firewood collection, harvesting of poles for construction and logging for timber on a marginal scale. Although surveyed households in Buyuni and Chanika for this study did not include forest related products among their primary and secondary sources of household income, anthropogenic activities in the forest reserves are quite prevalent. Denial to report the forest reserves as source of income was primarily contributed from their knowledge about the land tenure status of the forest reserves. The forests are purely designated for conservation and unauthorized extraction of any product from the forest is considered illegal. This illegal extraction of the forest products is at present very prevalent and have contributed to extensive land cover changes over the last forty years.

Analysis of land cover changes shows that closed forest cover for Kazimzumbwi forest reserve declined by $11.9 \%$ between 1980 and 1995 and by $41.3 \%$ between 1995 and 2010 (Table 1). The forest cover change was marked by increase in woodlands for the two window periods by $7.4 \%$ and $7.2 \%$ respectively. Decline of forest cover was associated with harvesting of logs for timber and felling of trees for construction purposes.

Table 1. Closed forest, woodland, bushland and grassland cover change for Kazimzumbwi and Pugu Forest reserves between 1980 and 2010.

\begin{tabular}{ccccc}
\hline \multirow{2}{*}{ Cover class } & \multicolumn{4}{c}{ Percentage Change } \\
\cline { 2 - 5 } & \multicolumn{2}{c}{ Kazimzumbwi } & \multicolumn{2}{c}{ Pugu } \\
\cline { 2 - 5 } & $(1980-1995)$ & $(1995-2010)$ & $(1980-1995)$ & $(1995-2010)$ \\
\hline Closed Forest & -11.9 & -41.0 & -4.5 & -25.3 \\
Woodland & 7.4 & 7.2 & 7.8 & 7.9 \\
Bushland & -5.2 & 22.3 & -2.7 & 12.3 \\
Grassland & 8.8 & 3.3 & -0.1 & 1.0 \\
Cultivated land & -0.5 & 0.0 & -2.3 & 0.0 \\
Settlement & 1.6 & 8.2 & 3.1 & 4.1 \\
\hline
\end{tabular}

Source: Mdemu et al. (2012). 
Although Bushland in the forest reserve declined by 5.2\% between 1980 and 1995, it increased by $22.3 \%$ between 1995 and 2010 . The land cover change for bushland was marked by increase in grasslands by $8.8 \%$ and 3.3\% between 1980 and 1995 and between 1995 and 2010. Conversion of woodlands into bushland and grassland can be associated with felling of trees for charcoal and firewood. A similar pattern of cover changes was depicted for Pugu forest reserve where forest cover declined in both window periods by $2.7 \%$ and $25.3 \%$ and woodlands consistently increased by $7.8 \%$ and $7.9 \%$ respectively. Bushland declined by $2.7 \%$ in the former period and increased by $12.3 \%$ in the latter period. These forest cover changes are results of intensified extraction of forest products from the forest reserves.

Communities surrounding the forest reserves largely depend on firewood and charcoal as their main source of energy. For example, $65 \%$ of the respondents in Buyuni (19\%), Chanika (18\%) and Masaki (28\%) during the period of this study reported to depend on firewood from Kazimzumbwi Forest Reserve (Table 2). Twelve percent (12\%) of the respondents reported to depend on charcoal as their main household source of energy while $18 \%$ depended on both firewood and charcoal. Not a single household reported to depend on either kerosene, gas and solar alone. The few households which indicated to use Kerosene, gas and solar energy combined these sources of energy either with firewood or charcoal. The use of firewood was more pronounced in Masaki which is characterized by rural setting compared to peri-urban areas of Buyuni and Chanika where the use of charcoal among the respondents was slightly higher than in Masaki.

Although local communities surrounding the Kazimzumbwi and Pugu forest reserves extract forest products, in particular firewood and charcoal for domestic household uses, extraction of forest products is largely done to supply the market in Dar es Salaam. The proximity to Dar es Salaam city which provide the main market for forest products encourage cutting of trees for charcoal, firewood and construction purposes. During the period of this study it was learnt that, the majority of the people coming to Kisarawe in connection to charcoal production were mainly from Dar es Salaam City where most of the charcoal produced in Kisarawe were being sold. The persistent increase in price of charcoal and firewood attracts people to engage in this activity. The

Table 2. Household energy use in the communities surrounding Kazimzumbwi Forest Reserve.

\begin{tabular}{cccc}
\hline \multirow{2}{*}{ Type of energy } & \multicolumn{3}{c}{ Household dependency on energy types (\%) } \\
\cline { 2 - 4 } Firewood & 19 & 18 & 28 \\
Buyuni $(\mathrm{n}=50)$ & Chanika $(\mathrm{n}=50)$ & Masaki $(\mathrm{n}=50)$ & Total $(\mathrm{N}=150)$ \\
\hline $\begin{array}{c}\text { Charcoal } \\
\text { Firewood \& Charcoal }\end{array}$ & 4 & 7 & 12 \\
$\begin{array}{c}\text { Kerosene, gas, solar } \\
\text { (in combination with } \\
\text { firewood \& Charcoal) }\end{array}$ & 8 & 7 & 3 \\
\hline
\end{tabular}


heightened charcoal business between rural and Dar es Salaam urban areas is a typical reflection of the energy use bias whereby fuel wood provides over 98 percent of energy in rural areas and approximately 90 percent in urban areas. In Dar es Salaam for example, the price of charcoal increased from Tshs 2500 per sack (approx $100 \mathrm{~kg}$ ) in 1998 to Tshs 4000 per sack in 2001. Current prices (2015) of the same sack stands at Tshs 50,000. The persistent increase price of charcoal motivates people to shift from the non-paying agricultural activities to off-farm activities including charcoal sale. According to Kahyarara et al. (2002) the sale of forest related products along the coastal forest zone attracted more financial returns compared to agriculture activities. While sales from agricultural products for farmers amounted to TShs 27,000 in one year, the average income from charcoal sellers averaged TShs 54,000 per year. The conclusion by Kahyarara et al. (2002) was that income generated from forest-related activities was higher and about twice the income generated through agricultural activities. It is not surprising therefore that shifting of people's livelihoods from typically agricultural to forest products is largely motivated among other factors by the comparably higher returns associated in the new activity. For communities surrounding Pugu and Kazimzumbwi forest reserves, Malugu (2007) found that income from charcoal per bag per annum was the second highest after crop production implying that communities were largely engaged in charcoal production as their alternative source of income after crop production. The abject poverty and lack of alternative livelihood strategies outside forest reserves characterizes communities surrounding the forest reserves. This makes harvesting and selling of forest products as the only easy and quick option to make living for majority of poor community members surrounding the forest reserves.

\subsection{Climate Change and Variability}

Communities perceived that climate variability and changes have occurred in the study areas over the last ten years. Some of the indicators of change and variability that community's use include decreasing rainfall trends, unpredictable rainfall patterns, increasing incidences of droughts, disappearance of wetlands and failure to predict on-set of rainy season using traditional indicators and indigenous knowledge. Local community members in Buyuni, Chanika and Masaki reported to experience declining rainfall pattern for the last ten years. Before 2003 they could receive good Vuli (short) and Masika (long) rains but currently Vuli rains have almost disappeared completely and Masika rains comes late (until April for some years) and stops earlier. Seventy four percent $(74 \%)$ of the respondents in the three communities perceived that the amount of rainfall in the study areas has been decreasing while only $20 \%$ of them considered rainfall amount to have remained the same (Table 3). In terms on rainfall onset during seasons, $63 \%$ of the respondents perceived it to be fluctuating implying that for some season's rainfall comes earlier than normal while for other seasons comes late.

Communities perception on climate change and variability corroborated in a very consistency way with the analysis of long term rainfall and temperature data (30 yrs) for Dar es Salaam and Kisarawe. Results of the analysis shows a declining rainfall trend 
Table 3. Community's perception on changes of rainfall amount and rainfall on-set over the past 10 years.

\begin{tabular}{cccccc}
\hline \multirow{2}{*}{ Variable } & \multirow{2}{*}{ Trend } & \multicolumn{4}{c}{ Percentage respondents } \\
\cline { 3 - 6 } & & $\begin{array}{c}\text { Buyuni } \\
(\mathrm{n}=50)\end{array}$ & $\begin{array}{c}\text { Chanika } \\
(\mathrm{n}=50)\end{array}$ & $\begin{array}{c}\text { Masaki } \\
(\mathrm{n}=50)\end{array}$ & $\begin{array}{c}\text { Total } \\
(\mathrm{N}=150)\end{array}$ \\
\hline \multirow{3}{*}{ Rainfall amount } & Increasing & 1 & 3 & 2 & 6 \\
& Decreasing & 28 & 29 & 17 & 74 \\
& The same & 4 & 2 & 14 & 20 \\
& Fluctuating & - & - & 1 & 1 \\
On set of rainfall & Tate in the season & 15 & 13 & 4 & 32 \\
& Too early in the season & 1 & 1 & 3 & 5 \\
& Fluctuating & 17 & 20 & 26 & 63 \\
\hline
\end{tabular}

in terms of rainfall amount and duration within and between seasons over the past five decades while temperatures have consistently increased during the same period (Kashaigili et al., 2014).

The inability of the farmers to use local or indigenous knowledge to determine onset of rains is one of the effects of the climate change and variability. Increased variability of rainfall pattern between seasons and years is complicating the determination of onset of rains using local or indigenous knowledge by the community members. In the past a number of indicators such as direction of moon, appearance of cluster of starts, certain types of insects, and appearance of certain types of clouds were being used by farmers to determine the onset of rain season (Table 4). Most of these indicators have disappeared and no longer used to determine the onset of rain seasons.

Only few indicators such as appearance of certain insects (Sangaugimbi, Vakule, Vibaruti, Vikanikani) and plants (Tindiga) are still in use to determine rainfall season. Apart from unpredictable rainfall patterns, extreme events such as heavy storms and flooding and droughts were reported by the communities. However, other climate change and variability indicators reported such as drying of Mzinga River might be more driven by local environmental change than climate change. Continued degradation of forest reserves have contributed to conversion of perennial rivers into seasonal rivers. Increased sedimentation in the river and wetlands contributed to the destruction of habitat resulting into disappearance of hippopotamus and fish. Changes in rainfall pattern, particularly recurrence of drought have considerably affected agriculture production in the study communities due to increased soil moisture stress. Recurrence droughts in the area are linked to increased frequency of extreme temperature $\left(>35^{\circ} \mathrm{C}\right)$ which coincides with Vuli and Masika crop seasons. Such droughts accelerate drought spells and contribute to crops failure due to increased evapotranspiration resulting into soil moisture stress when drought spell occurs. To cope with the effects of crop failure due to droughts, farmers especially men who do not have alternative income sources have shifted their livelihood activities towards extraction of forest products which include charcoal making, harvesting of construction materials and logging. 
Table 4. Community's perception of climate change and variability.

\begin{tabular}{|c|c|}
\hline Community & Indicators of changing climate and variability \\
\hline \multirow{4}{*}{ Buyuni } & Decreasing trend of rainfall \\
\hline & Unpredictable \\
\hline & Increasing incidences of droughts \\
\hline & Increasing food insecurity \\
\hline \multirow{10}{*}{ Chanika } & Unpredictable rainfall patterns compared to early 1990 s \\
\hline & Vuli (Oct/Nov-December) \\
\hline & Masika (Mar/April-June) \\
\hline & - $\quad$ Failure to predict on-set of rain season using the following \\
\hline & traditional indicators/indigenous knowledge \\
\hline & o Moon direction \\
\hline & Appearance of cluster of stars (kilimia na Mpini wa Kata) \\
\hline & Occurrence of insects (Mzungu, Nyenze) \\
\hline & Appearance of certain types of clouds \\
\hline & Increasing temperature trends \\
\hline
\end{tabular}

\section{Conclusion}

The study has established that rural-urban and internal urban migration in Dar es Salaam is one of the primary drivers of land cover dynamics in peri-urban areas and adjoining environments. This driver intensifies urban and peri-urban growth, land market and increased extraction of forest products. The increasing variability in rainfall accompanied with high temperature implies that rainfed agriculture dependent livelihoods are seriously compromised. In the absence of alternative livelihood strategies harvesting and selling of forest products will remain to be the only quick option to make living for majority of poor community members. Sustainable conservation of periurban forest requires strengthened enforcement measures in collaboration with communities surrounding the forest. Such measures should be supported with the development and implementation of land use plans that integrates peri-urban forest conservation.

\section{Acknowledgements}

This research was supported by a NORAD funded research programme-Climate Change Impacts, Adaptation and Mitigation (CCIAM) of the Sokoine University of Agriculture through Analysis of the Impacts of Urban Land Use and Climate Change on Coastal Forest Eco-system and Management research project.

\section{References}

Ahrends, A., Burgess, N. D., Milledge, S. A. H., Bulling, M.T., Fisher, B., Smart, J. C. R., et al., (2010). Predictable Waves of Sequential Forest Degradation and Biodiversity Loss Spreading from an African City. PNAS, 107, 14556-14561. http://dx.doi.org/10.1073/pnas.0914471107

Briggs, J., \& Mwamfupe, D. (1999). The Changing Nature of the Peri-Urban Zone in Africa: Evidence from Dar es Salaam, Tanzania. Scottish Geographical Journal, 115, 269-282. http://dx.doi.org/10.1080/00369229918737070

de Sherbinin, A. (2002). Land-Use and Land-Cover Change. A CIESIN Thematic Guide. Palisades, NY: Center for International Earth Science Information Network of Columbia University. http://sedac.ciesin.columbia.edu/tg/guide main.jsp 
Douglas, I. (2006). Peri-Urban Ecosystem and Societies: Transitional Zones and Contrasting Values. In D. McGregor, D., Simon, \& D. Thomson (Eds.), The Peri-Urban Interface (pp. 18-27). London: Earthscan.

Fragkias, M., Langanke, T., Boone, C.G., Haase, D., Marcotullio, P. J., Munroe, D., et al., (2012). Land Teleconnections in an Urbanizing World-A Workshop Report. GLP Report No. 5; GLP-IPO, Copenhagen. UGEC Report No. 6; UGEC-IPO, Tempe.

IHDP (2005). Science Plan: Urbanization and Global Environmental Change. Bonn: IHDP.

Kahyarara, G., Mbowe, W., \& Kimweri, O. (2002). Poverty and Deforestation around the Gazetted Forests of the Coastal Belt of Tanzania. Research Report No. 02.3, Research on Poverty Alleviation (REPOA). Dar es Salaam: Mkuki na Nyota Publishers.

Kashaigili, J. J., Levira, P., Liwenga, E., \& Mdemu, M. V. (2014) Analysis of Climate Variability, Perceptions and Coping Strategies of Tanzanian Coastal Forest Dependent Communities. American Journal of Climate Change, 3, 212-222. http://dx.doi.org/10.4236/ajcc.2014.32020

Kebede, A. S., \& Nicholls, R. J. (2011). Population and Assets Exposure to Coastal Flooding in Dar es Salaam (Tanzania): Vulnerability to Climate Extremes. Regional Environ Change, 12, 81-94.

Kironde, J. M. L. (2001). Peri-Urban Land Tenure, Planning and Regularisation: Case Study of Dar es Salaam, Tanzania. Harare: Municipal Development Programme.

Kombe, W. (2010). Land conflicts in Dar es Salaam: who gains? who loses? working paper no. 82 - cities and fragile states, UKaid/Crisis States Research Centre ISSN 1749-1800

Lupala, A. (2001). Land Management in the Peri-Urban Zone of Rapidly Growing Cities. The Case of Dar es Salaam. PhD Thesis, Dortmund: Technical University of Dortmund, 306p

Lupala, J. (2002). Urban Types in Rapidly Urbanizing Cities-Analysis of Formal and Informal Settlements in Dar es Salaam, Tanzania. Doctoral Thesis, Stockholm: Royal Institute of Technology.

Malugu, I. O. E. (2007). Resource-Use Conflicts and Management Challenges for Pugu and Kazimzumbwi Forest Reserves in Kisarawe and Ilala Districts, Tanzania. Discovery and Innovation, 19, 149-174.

Mdemu, M., Kashaigili, J.J., Lupala, J., Levira, P., Liwenga, E., Nduganda, A. et al., (2012). Dynamics of land use and land cover changes in the Pugu and Kazimzumbwi Forest Reserves. In Proceedings of the First CCIAM Scientific Conference (pp. 54-77). Morogoro: Sokoine University of Agriculture.

Msangi, D. E. (2011). Land Acquisition for Urban Expansion: Process and Impacts on Livelihoods of Peri Urban Households, Dar es Salaam, Tanzania. Licentiate Thesis, Uppsala: Swedish University of Agricultural Sciences.

Muzzini, E., \& Lindeboom, W. (2008). The Urban Transition in Tanzania: Building the Empirical Base for Policy Dialogue (166 p). Washington, DC: The World Bank.

Tockner, K., \& Stanford, J. A. (2002). Riverine Flood Plains: Present State and Future Trends. Environmental Conservation, 29, 308-330. http://dx.doi.org/10.1017/S037689290200022X

Wang, Y., Tobey, J., Nugranad, G. B. J., Makota, V., Ngusaru, A., \& Traber, M. (2005). Involving Geographical Information in the Analysis of Land-Cover Change along the Tanzania Coast. Coastal Management, 33, 87-99. http://dx.doi.org/10.1080/08920750590883132 
Submit or recommend next manuscript to SCIRP and we will provide best service for you:

Accepting pre-submission inquiries through Email, Facebook, LinkedIn, Twitter, etc. A wide selection of journals (inclusive of 9 subjects, more than 200 journals)

Providing 24-hour high-quality service

User-friendly online submission system

Fair and swift peer-review system

Efficient typesetting and proofreading procedure

Display of the result of downloads and visits, as well as the number of cited articles

Maximum dissemination of your research work

Submit your manuscript at: http://papersubmission.scirp.org/ 